\title{
PIELEEGNIARSTWO - ZAWÓD SZCZEGÓLNIE NARAŻONY NA STRES I WYPALENIE. WYBRANE ZAŁOŻENIA TEORETYCZNE I WSTĘPNE DONIESIENIE Z BADAŃ - CZĘŚĆ I*
}

\author{
NURSING - PROFESSION PARTICULARLY VULNERABLE TO STRESS AND BURNOUT. \\ SELECTED THEORETICAL ASSUMPTIONS AND PRELIMINARY RESEARCH REPORT-PART I*
}

\author{
Iwona Nowakowska ${ }^{1}$, Renata Rasińska ${ }^{1}, K^{2}$ atarzyna Roszak², Agnieszka Bańkowska ${ }^{3}$ \\ ${ }^{1}$ Zakład Organizacji i Zarządzania w Opiece Zdrowotnej \\ Uniwersytet Medyczny im. Karola Marcinkowskiego w Poznaniu \\ ${ }^{2}$ Wydział Nauk o Zdrowiu \\ Uniwersytet Medyczny im. Karola Marcinkowskiego w Poznaniu \\ ${ }^{3}$ Zakład Higieny i Epidemiologii \\ Collegium Medicum im. Ludwika Rydygiera w Bydgoszczy, Uniwersytet Mikołaja Kopernika w Toruniu
}

DOI: https://doi.org/10.20883/pielpol.2017.16

\section{STRESZCZENIE}

Cel. Prezentacja wybranych założeń teoretycznych w zakresie wypalenia zawodowego oraz analiza wstępna wyników badań dotyczących subiektywnego odczuwania symptomów tego zjawiska wśród pielęgniarek.

Materiał i metody. W badaniu wzięło udział 111 pielęgniarek zatrudnionych w poznańskim szpitalu. Wyniki zgromadzono na podstawie wypełnionych kwestionariuszy ankiety CBI.

Wnioski. Pielęgniarki doświadczają niepokojących symptomów, mogących świadczyć o zmęczeniu, wyczerpaniu fizycznym lub emocjonalnym, zarówno w aspekcie życia osobistego, związanego z pracą, jak i obejmującego kontakty z pacjentami.

SŁOWA KLUCZOWE: pielęgniarstwo, stres, wypalenie.

\section{Wstęp}

Pielęgniarki stanowią grupę zawodową szczególnie narażoną na zjawisko wypalenia zawodowego. W swojej pracy spotykają się z wieloma czynnikami, które mogą doprowadzić do sytuacji wskazujących na pojawienie się znamion wypalenia. Wśród nich należy wymienić:

- $\quad$ specyficzne cechy zawodu - praca zmianowa, także w godzinach nocnych, kontakt z pacjentem, który może doprowadzić do zarażenia się, styczność z materiałem biologicznym, wykonywanie czynności przy zabiegach czy pielęgnacja chorego;

- obciążenia psychiczne - odpowiedzialność przy podawaniu leków czy wykonywaniu zabiegów, świadomość skutków sytuacji, w której popełnia się błąd, konieczność zachowywania wrażliwości na ból, cierpienie czy śmierć pacjenta;

\section{ABSTRACT}

Aim. Presentation of selected theoretical assumptions in the area of occupational burnout and preliminary analysis of the research results concerning subjective experience of the symptoms of this phenomenon among nurses.

Material and methods. A total of 111 nurses employed in a Poznań hospital took part in the study. The results were collected on the basis of completed CBI questionnaires.

Conclusions. Nurses experience worrying symptoms that may indicate fatigue, physical or emotional exhaustion, in the personal aspect of life as well as work-related and involving contacts with patients.

KEYWORDS: nursing, stress, burnout.

- brak możliwości leczenia lub jej ograniczenia - brak leków czy sprzętu medycznego, ograniczona liczba pielęgniarek w stosunku do liczby pacjentów, nieodpowiednie warunki lokalowe, zła organizacja pracy;

- $\quad$ niewspółmierne zarobki do wymagań oraz pracy wkładanej w wykonywanie swoich obowiązków, niższe zarobki w stosunku do innych grup zawodowych;

- $\quad$ niski status zawodowy - obniżony prestiż, brak uznania przez społeczeństwo wysiłku wkładanego w pracę;

- brak współpracy z innymi pracownikami sprzeczne polecenia przełożonych, przenoszenie odpowiedzialności za skutki leczenia, utrudniony kontakt z innymi pracownikami, bagatelizowanie pracy pielęgniarek; 
- $\quad$ niewłaściwa relacja z pacjentami i ich rodzinami - brak szacunku dla pracy pielęgniarki, zbyt wysokie wymagania, brak uznania [1, 2].

Zgodnie z podziałem zaproponowanym przez Aronsona objawy wypalania zawodowego można podzielić na trzy kategorie. Pierwszą stanowi wyczerpanie fizyczne, charakteryzujące się: utratą energii, nieustannym zmęczeniem, podatnością na wypadki, napięciem mięśni, bólami pleców, zmianą przyzwyczajeń żywieniowych, skłonnością do przeziębień, występowaniem koszmarów sennych, spożywaniem większej ilości leków, używek. Kolejną kategorię stanowi wyczerpanie emocjonalne: uczucie smutku, bezradności, braku wyjścia i perspektyw, płaczliwość, rozczarowane, odczucie pustki, nadpobudliwość, ogólne zniechęcenie. Wyczerpanie psychiczne to trzecia zdefiniowana kategoria, objawiająca się: krytycznym stosunkiem do pracy oraz siebie, do życia, cynizmem i lekceważącym stosunkiem do pacjentów, brakiem szacunku do samego siebie, utratą poczucia własnej wartości, zerwaniem kontaktów z kolegami, bliskimi [3].

Badając zjawisko wypalenia zawodowego, Maslach oraz Jackson wyróżniły dwie grupy zmiennych: czynniki mogące sprzyjać wypaleniu oraz zachowania pomagające skutecznie walczyć z wypaleniem. Efektem badań było wyklarowanie się charakterystycznego obrazu dla wypalenia zawodowego wśród pielęgniarek. Zjawisko to rośnie wraz ze wzrostem przydzielanych zadań lub spadkiem możliwości podejmowania decyzji w pracy. Czynniki te powodują odczuwanie emocjonalnego wyczerpania oraz skłonność do depersonalizacji pacjentów. Depersonalizacja rośnie wówczas, kiedy spada ilość informacji zwrotnych pochodzących od pacjentów [4]. Według badań Jackson i Schuler ryzyko wystąpienia wypalenia zawodowego wzrasta wraz z brakiem możliwości kontroli otoczenia. Stwierdzenie to zostało oparte na założeniu, że otoczenie nagradzające dla pracownika to takie, na które może wpływać, natomiast otoczenie niekorzystne to takie, w którym możliwość kontroli jest ograniczona. Dla pielęgniarek wskaźnikiem kontroli jest otrzymywanie zwrotnych informacji od pacjentów oraz możliwość podejmowana decyzji dotyczących wykonywania procedur przy pacjencie. Kiedy kontrola spada, rośnie depersonalizacja. Taka sytuacja powoduje wzrost konfliktów powiązanych z pełnioną rolą. Niesprecyzowana rola nie umożliwia wyznaczenia granicy kontroli, co powoduje wyczerpanie emocjonalne oraz spadek poczucia osiągnięć. Konflikt roli powoduje także cynizm w stosunku do pacjenta. Poczucie kontroli oraz możliwość decyzji daje pielęgniarkom siłę do walki z trudnościami swojego zawodu [5].
Konsekwencje wypalenia zawodowego są bardzo rozległe i mogą dotyczyć kilku obszarów życia. Oprócz sfery zawodowej mogą oddziaływać także na zdrowie fizyczne i psychiczne oraz negatywnie wpływać na relacje rodzinne.

Wypalenie zawodowe ma swoje konsekwencje zdrowotne. Najczęściej są to: bóle głowy, mięśni, problemy ze snem, choroby układu pokarmowego czy choroby kardiologiczne. Pracownik może odczuwać także złe samopoczucie, zmianę apetytu, mogą pojawiać się problemy ze zmianą wagi. Bardzo często występują uzależnienia od środków psychoaktywnych. Konsekwencje zdrowotne mogą być odczuwane także w sferze zdrowia psychicznego. U osób wypalonych można zaobserwować: zaniepokojenie, skłonność do depresji, poczucie lęku, odczuwanie nieustannych porażek, niską samoocenę, brak akceptacji samego siebie [2].

Następstwa organizacyjne wypalenia zawodowego to przede wszystkim: obniżenie jakości i wydajności pracy, częsta absencja chorobowa, koszty związane z koniecznością przekwalifikowania nowego pracownika czy konflikty pracownicze. Pracownik, po okresie pełnego zaangażowania, motywacji, staje się antypatyczny i zniechęcony do pracy [6]. Wśród następstw wypalenia zawodowego można również wymienić: zwiększone ryzyko wypadków w pracy, częste zmiany pracy, wcześniejsze przechodzenie na emeryturę czy odchodzenie z wybranego zawodu. Konsekwencje wypalenia zawodowego są szczególnie dotkliwe, jeśli dotykają pracowników medycznych. Mogą doprowadzić do bycia obojętnym w stosunku do pacjentów, ich problemów czy potrzeb, co w konsekwencji prowadzi do braku zadowolenia z opieki medycznej ze strony pacjenta czy nawet rezygnacji $z$ dalszego leczenia [7]. Trudne do zniesienia przez personel medyczny są także wymagania pacjentów. Pracownicy medyczni pracują coraz więcej. Stopniowo dystansują się od pacjentów, unikając kontaktów, spotkań z pacjentem, nadzorują, a nie opiekują się. Takie zachowane jest bardzo negatywnie oceniane, co u pracowników wywołuje odczucie braku sensu pracy, braku kompetencji, rozczarowanie [8].

Konsekwencje wypalenia zawodowego mogą być odczuwane także w sferze życia rodzinnego. Pracownik jest nerwowy, przewrażliwiony, konfliktowy, wyczerpany emocjonalne, co powoduje narastanie nieporozumień także w życiu osobistym. Brak okazywania empatii przy jednoczesnym okazywaniu większej wrogości powoduje spadek relacji interpersonalnych w rodzinie [2].

\section{Cel}

Cele to prezentacja wybranych założeń teoretycznych w zakresie wypalenia zawodowego oraz analiza wstępna wyników badań dotyczących subiektywnego odczu- 
wania symptomów tego zjawiska (w aspekcie wypalenia osobistego, związanego z pracą oraz związanego z pacjentami) wśród pielęgniarek.

\section{Materiał i metody}

W badaniu ankietowym wzięło udział 111 pielęgniarek zatrudnionych w szpitalu na terenie Poznania. Spośród ankietowanych pielęgniarek $40 \%$ należy do grupy wiekowej do 35 lat, w wieku 36-45 lat jest 19\% respondentek, zaś $28 \%$ deklaruje przynależność do grupy 46-55 lat. Powyżej 55. roku życia jest 13\% pielęgniarek. Wyższe wykształcenie ma 53\% osób, a $47 \%$ - średnie medyczne. Aż 35\% pielęgniarek biorących udział w badaniu deklaruje staż pracy powyżej 26 lat, staż od 16 lat do 25 lat wskazało $21 \%$, natomiast w przedziale 6-15 lat pracuje 20\% kobiet. Najmłodsze pielęgniarki, których staż pracy nie przekracza 5 lat, stanowią 24\% ogółu ankietowanych. Większość pielęgniarek zatrudniona jest w systemie pracy zmianowej (81\%), natomiast $19 \%$ pracuje w systemie jednozmianowym. Dla 19\% kobiet blok operacyjny jest podstawowym miejscem pracy, w oddziale anestezjologicznym zatrudnionych jest $15 \%$ pielęgniarek, w neurologicznym - 16\%, w chirurgicznym - 14\%. Pozostałe pielęgniarki zatrudnione są w izbie przyjęć (9\%), oddziale urologicznym $(9 \%)$, hematologicznym (8\%), ortopedycznym (5\%) oraz chorób wewnętrznych i kardiologii (5\%).

Wyniki zgromadzono, wykorzystując kwestionariusz ankiety Kopenhaskiego Inwentarza Wypalenia Zawodowego (ang. Copenhagen Burnout Inventory - CBI) [9].

\section{Wyniki}

Na podstawie danych zgromadzonych podczas badania ankietowego z użyciem kwestionariusza CBI zaprezentowano udział otrzymanych od respondentek odpowiedzi w oparciu o trzy wyodrębnione rodzaje wypalenia: wypalenie osobiste, wypalenie związane z pracą oraz wypalenie w kontaktach z pacjentem.

W przypadku wypalenia osobistego aż 49\% pielęgniarek deklaruje stan częstego odczuwania zmęczenia, 39\% odczuwa je czasami, a 4\% - zawsze. Odpowiedź: rzadko wskazało $8 \%$ kobiet. Często i czasami odczuwa wyczerpanie fizyczne po $39 \%$ pielęgniarek, natomiast rzadko wyczerpanych fizycznie jest 18\% osób. Aż $40 \%$ kobiet twierdzi, że czasami są wyczerpane emocjonalnie, a 29\% stan ten określa jako częsty. Rzadko wyczerpanie emocjonalne towarzyszy $25 \%$ ankietowanych. Myśl „nie mogę dłużej już tego znieść” często i czasami pojawia się u $43 \%$ osób, natomiast rzadko lub nigdy u 56\% respondentek. Na pytanie, jak często pielęgniarki czują się wykończone, odpowiadają, że u 33\% ten stan występuje czasami, u 24\% - często, u 27\% - rzadko, a $15 \%$ nie odczuwa go wcale. Osłabienie oraz podat- ność na zachorowania czasami obserwuje u siebie 35\% kobiet, 34\% - rzadko, 19\% - często, zaś 9\% - nigdy.

W kolejnym etapie dokonano analizy udzielonych odpowiedzi definiujących obszar wypalenia związanego z pracą. Na pytanie, czy praca zawodowa jest wyczerpująca emocjonalnie, aż 65\% pielęgniarek twierdzi, że tak - w bardzo dużym lub dużym stopniu, 25\% wskazuje odpowiedź: trochę, zaś dla 10\% wyczerpanie emocjonalne związane z pracą występuje w małym lub bardzo małym zakresie. Stan frustracji w związku z wykonywaną pracą deklaruje, udzielając odpowiedzi: trochę, 34\% kobiet, w dużym i bardzo dużym stopniu - 25\%, zaś w małym lub bardzo małym stopniu - $41 \%$ pielęgniarek. Aż 40\% respondentek czuje się wykończone pod koniec dnia pracy, czasami taki stan odczuwa 34\% kobiet, a zawsze - $12 \%$. Odpowiedzi: rzadko lub nigdy udzieliło $14 \%$ ankietowanych. Poranne wyczerpanie na myśl o kolejnym dniu pracy oraz refleksja, że każda godzina pracy jest męcząca, występują u pielęgniarek biorących udział w badaniu: zawsze $(6 \%, 3 \%)$, często $(15 \%$, $14 \%)$, czasami (38\%, 38\%), rzadko $(26 \%, 34 \%)$ oraz nigdy (15\%, 11\%). Na pytanie, czy respondentki czują się wypalone z powodu wykonywanej pracy, odpowiedzi: w dużym i bardzo dużym stopniu udzieliło $24 \%$ kobiet, odpowiedź: trochę wskazało $30 \%$, a w małym lub bardzo małym stopniu poczucie takie ma $46 \%$ ankietowanych. Ostatnie pytanie w tej części dotyczyło oceny pokładów energii dla rodziny i przyjaciół w wolnym czasie; czy jest ona wystarczająca. Pielęgniarki w tym zakresie wybrały odpowiedzi: zawsze (13\%), często (31\%), czasami (32\%) oraz rzadko (22\%) i nigdy/prawie nigdy (2\%).

W trzeciej części respondentki udzielały odpowiedzi na pytania charakteryzujące obszar wypalenia w kontaktach z pacjentami. Na pytanie: „Czy uważa Pani, że praca z pacjentami jest trudna?" najwięcej ankietowanych odpowiedziało, że w dużym stopniu tak (52\%). W dalszej kolejności pielęgniarki wybierały odpowiedź: trochę (20\%) oraz w bardzo dużym stopniu (18\%). Odpowiedź: w małym stopniu wybrało $7 \%$ ankietowanych, najmniej (3\%) wskazało odpowiedź: w bardzo małym stopniu. Wysoki odsetek odpowiedzi świadczących o tym, że praca z pacjentem jest trudna w dużym i bardzo dużym stopniu (70\%), może być dowodem na trudności, jakie spotykają pielęgniarki w codziennych kontaktach z pacjentem i jego rodziną. Na kolejne pytania dotyczące oceny, czy praca z pacjentami jest frustrująca oraz czy pozbawia pielęgniarki energii, uzyskano odpowiednio następujące odpowiedzi: w dużym lub bardzo dużym stopniu (18\%, 18\%), trochę (37\%, 35\%), w małym lub bardzo małym stopniu (45\%, 47\%). Przeanalizowano odpowiedzi na pytanie: „Czy czuje Pani, że pracując z pacjentami, daje więcej, niż otrzymuje w zamian?". Pielęgniarki w bardzo dużym (13\%), du- 
żym (23\%) stopniu lub trochę (39\%) widzą dysproporcje w badanym obszarze. Odpowiedzi: w małym (17\%) oraz w bardzo małym (8\%) stopniu udzieliło łącznie $25 \%$ kobiet. Czasami zmęczenie pracą z pacjentami deklaruje $39 \%$ pielęgniarek, często takie uczucie ma $20 \%$, a zawsze $-2 \%$ kobiet. Brak zmęczenia pracą z pacjentami deklaruje $10 \%$ pielęgniarek, a rzadko poczucie to doskwiera 29\% ankietowanych. Spośród respondentek $37 \%$ czasami myśli o tym, jak długo będzie w stanie kontynuować pracę z pacjentami. Często zadaje sobie to pytanie $23 \%$ osób, rzadko - $20 \%$, a nigdy lub prawie nigdy - $15 \%$ pielęgniarek.

\section{Wnioski}

1. Wśród ankietowanych pielęgniarek występują niepokojące symptomy, mogące świadczyć o zmęczeniu, wyczerpaniu fizycznym lub emocjonalnym zarówno w aspekcie życia osobistego, związanego z pracą, jak i obejmującego kontakty z pacjentami.

2. Pielęgniarki bardziej pejoratywnie oceniają obszar związany w pracą aniżeli obszar związany z kontaktami z pacjentami.

\section{Podsumowanie}

Wypalenie zawodowe jest zjawiskiem bardzo złożonym. Badacze tego problemu uważają, że wypalenie powstaje w efekcie długotrwałego stresu, dlatego przeciwdziałanie temu zjawisku powinno być związane z działaniami antystresowymi. Prewencja pierwotna dotyczy warunków pracy. Powinno się ocenić możliwość wystąpienia ryzyka stresu w miejscu pracy, a następnie wyeliminować czynniki, które go wywołują. Prewencja wtórna skierowana jest na zmiany w człowieku, nie w środowisku pracy. Pracownik powinien nauczyć się, jak poradzić sobie ze stresem. Prewencja trzeciorzędowa polega na wyleczeniu skutków zdrowotnych stresu [1].

Według Sęk przeciwdziałać wypaleniu zawodowemu można poprzez uczucie poznawczej kontroli, która jest oparta na własnych doświadczeniach, nastawieniu na zmianę własnej osoby oraz odczuciu własnej efektywności zawodowej. Przeciwdziałać wypaleniu zawodowemu można także poprzez zwiększenie odczucia własnych kompetencji zawodowych. Aby przeciwdziałać wypaleniu zawodowemu, powinno się stosować odpowiednie strategie, strategie pozytywne, czyli nauczyć pracowników radzenia sobie ze stresem. Ważne są także pozytywnie ocenianie własnego doświadczenia życiowego oraz możliwość kontrolowania sytuacji zawodowej. Strategie negatywne polegają na minimalizowaniu czynników ryzyka i eliminacji niedogodności zawodowych, takich jak niska płaca czy niski status społeczny. W walce ze stresem istotne są także optymalny wypoczynek, rozwijanie hobby i kreatywne spędzanie czasu. Powinno się eliminować irracjonalne nastawienie czy chęć ucieczki [10,11].

Zgodnie ze schematem Schaufeliego i Enzmanna przeciwdziałanie wypaleniu zawodowemu powinno odbywać się na trzech płaszczyznach:

- $\quad$ indywidualnej - przeciwdziałanie skutkom stresu poprzez odwołanie się do indywidualnych reakcji na czynniki stresujące. Jednym ze sposobów jest strategia służąca samopoznaniu pracownika. Istotne są także powadzenie zdrowego trybu życia czy stosowanie technik relaksacji w domu i w pracy;

- indywidualno-instytucjonalnej - zwiększanie odporności pracownika na stresory występujące w środowisku zawodowym. Istotne są nauczenie pracownika, jak ma radzić sobie ze stresem zawodowym, zwiększenie świadomości na temat własnych możliwości, nauka jak najefektywniejszego wykorzystywania czasu czy ustalania priorytetów. Ważne są także umożliwienie rozwoju kariery oraz wsparcie ze strony współpracowników czy tworzenie koleżeńskiej atmosfery. Powinny być także prowadzone treningi interpersonalne dotyczące wypalenia zawodowego, radzenia sobie ze stresem;

- $\quad$ instytucjonalnej - skupia się na podnoszeniu jakości wykonywanej pracy oraz obniżaniu kosztów. Ważne jest, aby regularnie przeprowadzać anonimowe badania wśród pracowników w celu określenia stopnia występowania stresu oraz wypalenia zawodowego. Pracownicy powinni mieć możliwość przeprowadzenia badania oceniającego, czy występują u nich symptomy wypalenia. Organizacja powinna dążyć do ulepszenia środowiska pracy poprzez: poprawę komunikacji, zapobieganie konfliktom, urlopy szkoleniowe itd. Za istotne uważa się także wprowadzenie elastycznego planu pracy, sprawiedliwe zarządzanie oraz precyzyjne określenie obowiązków zawodowych. Pracownicy powinni mieć także możliwość skorzystania z pomocy profesjonalistów z zakresu wypalenia zawodowego [1, 7].

Przeciwdziałać wypaleniu zawodowemu można także, pracując zgodnie ze zdobytym wykształceniem i umiejętnościami, a także poprzez rozwijanie własnej osobowości, umiejętną samoocenę i ocenę rzeczywistości oraz poprzez radzenie sobie w sytuacjach stresowych. Istotne jest także, aby przeznaczać czas na odpoczynek oraz odcinać się od problemów zawodowych w czasie wolnym. Pracownicy, którzy się „nie wypalają", to tacy, którzy angażują się w swoje zadania 
zawodowe, ale nie są nastawieni na rywalizowanie ze współpracownikami. Można zaobserwować, że podatność na występowanie zjawiska wypalenia zawodowego zależna jest od: zasobów podmiotowych (umiejętności zawodowe, kontakty międzyludzkie, komunikacja), zasobów przedmiotowych (warunki finansowe, dodatkowe świadczenia socjalne), umiejętności poradzenia sobie ze stresem, rozwiązywania konfliktów, zapewnienia odpowiedniego wypoczynku, a także otrzymywanego wsparcia społecznego [12].

\section{Piśmiennictwo}

1. Wyderka M, Kowalska H, Szeląg E. Wypalenie zawodowe jako problem występujący wśród pielęgniarek. Piel Pol. 2009; 4(34): 265-275.

2. Wilczek-Rużyczka E. Wypalenie zawodowe pracowników medycznych. Warszawa: Wolters Kluwer; 2014.

3. Litzke MS, Schuh H. Stres, mobbing i wypalenie zawodowe. Gdańsk: GWP; 2007.

4. Beisert M. Przejawy, mechanizmy i przyczyny wypalania się pielęgniarek. W: Sęk H (red.). Wypalenie zawodowe - przyczyny, mechanizmy, zapobieganie. Warszawa: PWN; 2000.

5. Terelak JF. Stres zawodowy. Charakterystyka psychologiczna wybranych zawodów stresowych. Warszawa: Wyd. Uniwersytetu Kardynała Stefana Wyszyńskiego; 2007.

6. Erenkfeit K, Dudzińska L, Indyk A. Wpływ środowiska pracy na powstanie wypalenia zawodowego. Med Środ - Env Med. 2012; 15(3): 121-128.

7. Anczewska M. Stres i wypalenie zawodowe u pracowników psychiatrycznej opieki zdrowotnej. Warszawa: Instytut Psychiatrii i Neurologii; 2006.

8. Ogińska-Bulik N. Stres zawodowy w zawodach usług społecznych. Źródła - konsekwencje - zapobieganie. Warszawa: Wyd. Difin; 2006.

9. Kristensen TS, Borritz M. Copenhagen Burnout Inventory: Normative Data from a representative Danish population on Personal Burnout and Results from the PUMA study on Personal Burnout, Work Burnout, and Client Burnout, $\mathrm{Na}-$ tional Institute of Occupational Health, Copenhagen 2004, http://www.arbejdsmiljoforskning.dk/upload/omi/copenhagen\%20burnout $\% 20$ inventory\%20\%20normative $\% 20$ data\%20from\%20a\%20representative\%20danish\%20population.pdf (data dostępu: 17.06.2016).

10. Sęk H. Uwarunkowania i mechanizmy wypalenia zawodowego w modelu społecznej psychologii poznawczej. W: Sęk H (red.). Wypalenie zawodowe - przyczyny, mechanizmy, zapobieganie. Warszawa: PWN; 2000.

11. Fiłończuk-Wieczorkowska H, Żukrowska M. Praktyczne wskazówki terapii niefarmakologicznej. Radzenie sobie w zapobieganiu i leczeniu zespołu wypalenia zawodowego. W: Steciwko A, Mastalerz-Migas A (red.). Stres oraz wypalenie zawodowe. Jak rozpoznać, zapobiegać i leczyć. Wrocław: Elsevier Urban \& Partner; 2012.

12. Dawidziuk K, Lishchynskyy Y, Wojciechowska M, Kopański Z, Marczewska S, Uracz W. Skutki wypalenia zawodowego i sposoby radzenia sobie ze stresem. J Publ Health Nurs Med Rescue. 2011; 4: 23-25.

* Artykuł zawiera obszerne fragmenty przygotowywanej pracy magisterskiej, realizowanej przez lic. Katarzynę Roszak na Wydziale Nauk o Zdrowiu, w Zakładzie Organizacji i Zarządzania w Opiece Zdrowotnej Uniwersytetu Medycznego im. Karola Marcinkowskiego w Poznaniu, pod kierunkiem dr inż. Iwony Nowakowskiej.

Artykuł przyjęty do redakcji: 21.07.2016

Artykuł przyjęty do publikacji: 25.08.2016

Źródło finansowania: Praca nie jest finansowana z żadnego źródła. Konflikt interesów: Autorzy deklarują brak konfliktu interesów.

Adres do korespondencji:

Iwona Nowakowska

ul. Mariana Smoluchowskiego 11

60-179 Poznań

tel.: 618612221

e-mail: iwonanowakowska@op.pl

Zakład Organizacji i Zarządzania w Opiece Zdrowotnej

Uniwersytet Medyczny im. Karola Marcinkowskiego w Poznaniu 